\title{
Pots vs trammel nets: a catch comparison study in a Mediterranean small-scale fishery
}

\author{
Andrea Petetta ${ }^{\text {Corresp.. Equal first author, } 1,2}{ }^{2}$, Claudio Vasapollo ${ }^{\text {Equal frst author, } 2}{ }^{2}$, Massimo Virgili ${ }^{2}$, Giada Bargione ${ }^{1,2}$, Alessandro \\ Lucchetti ${ }^{\text {Corresp. } 2}$ \\ ${ }^{1}$ Department of Biological, Geological and Environmental Sciences, University of Bologna, Bologna, Italy, Italy \\ 2 Institute for Biological Resources and Marine Biotechnologies (IRBIM), Italian National Research Council (CNR), Ancona, Italy, Italy \\ Corresponding Authors: Andrea Petetta, Alessandro Lucchetti \\ Email address: andrea.petetta@irbim.cnr.it, alessandro.lucchetti@cnr.it
}

Passive bottom-set nets are the most widely used fishing gears in Mediterranean smallscale fisheries (SSFs). Trammel nets, in particular, have key advantages such as their ease of use and handling and high capture efficiency for numerous commercial species. However, they entail high discard rates (5-44\% of the total catch) connected to high mortality, thus exerting an adverse impact on benthic communities, besides catching individuals of commercial species under the minimum conservation reference size (MCRS) and specimens of protected species. Fish pots are seen as alternative and a more sustainable gear type that allow reducing discards in SSFs. In this study, a collapsible pot was tested at three coastal sites in the north-western Adriatic Sea (GFCM GSA 17) to compare its catch efficiency with that of the local traditional trammel nets. Data analysis demonstrated a similar catch efficiency for the commercial species, both among sites and as a whole. Moreover, the trammel net caught a larger amount of discards, both in terms of species number and of CPUEw. The catch comparison study involved the two most abundant landed species, common cuttlefish Sepia officinalis and annular sea bream Diplodus annularis. The pots were more effective for $S$. officinalis, whereas the trammel net was more effective for the shorter length classes for $D$. annularis, which were mostly under the MCRS (12 cm). The innovative pots could provide a valuable alternative to the trammel nets traditionally used in the Adriatic Sea, at least in certain areas and periods. Their main advantages include that they do not require a different rigging and they can be used without bait, while their foldable design allows large numbers to be easily loaded on board SSF vessels. The results of this pilot study indicate that pots can achieve the objectives of reducing discards and bycatch in SSFs without penalizing the catch of commercial species. 
1 Pots vs trammel nets: a catch comparison study in a

2 Mediterranean small-scale fishery

3

4

5

6

7

8

\author{
Andrea Petetta ${ }^{1,2}$, Claudio Vasapollo ${ }^{1}$, Massimo Virgili ${ }^{1}$, Giada Bargione ${ }^{1,2}$, Alessandro \\ Lucchetti ${ }^{1}$ \\ ${ }^{1}$ Institute for Biological Resources and Marine Biotechnologies (IRBIM), National Research \\ Council (CNR), Ancona, Italy \\ ${ }^{2}$ Department of Biological, Geological and Environmental Sciences, University of Bologna, \\ Bologna, Italy
}

Corresponding Authors: Alessandro Lucchetti ${ }^{1}$, Andrea Petetta ${ }^{1,2}$

Largo Fiera della Pesca, Ancona, 1, 60125, Italy

Email addresses: alessandro.lucchetti@,cnr.it; andrea.petetta@,irbim.cnr.it

\title{
Abstract
}

Passive bottom-set nets are the most widely used fishing gears in Mediterranean small-scale fisheries (SSFs). Trammel nets, in particular, have key advantages such as their ease of use and handling and high capture efficiency for numerous commercial species. However, they entail high discard rates (5-44\% of the total catch) connected to high mortality, thus exerting an adverse impact on benthic communities, besides catching individuals of commercial species under the minimum conservation reference size (MCRS) and specimens of protected species. Fish pots are seen as alternative and a more sustainable gear type that allow reducing discards in SSFs. In this study, a collapsible pot was tested at three coastal sites in the north-western Adriatic Sea (GFCM GSA 17) to compare its catch efficiency with that of the local traditional trammel nets. Data analysis demonstrated a similar catch efficiency for the commercial species, both among sites and as a whole. Moreover, the trammel net caught a larger amount of discards, both in terms of species number and of $\mathrm{CPUE}_{\mathrm{w}}$. The catch comparison study involved the two most abundant landed species, common cuttlefish Sepia officinalis and annular sea bream Diplodus annularis. The pots were more effective for S. officinalis, whereas the trammel net was more effective for the shorter length classes for $D$. annularis, which were mostly under the MCRS $(12 \mathrm{~cm})$. The innovative pots could provide a valuable alternative to the trammel nets traditionally used in the Adriatic Sea, at least in certain areas and periods. Their main advantages include that they do not require a different rigging and they can be used without bait, while their foldable design allows large numbers to be easily loaded on board SSF vessels. The results of this pilot study indicate that pots can achieve the objectives of reducing discards and bycatch in SSFs without penalizing the catch of commercial species. 


\section{Introduction}

41 Gillnets and trammel nets (or set/passive nets) are the most widely used fishing gears in

42

43

44

45

46

47

48

49

50

51

52

53

54

55

56

57

58

59

60

61

62

63

64

65

66

67

68

69

70

71

72

73

74

75

76

77

78 Mediterranean small-scale fisheries (SSFs) (Lucchetti et al., 2015), which account for more than 70,000 vessels (FAO, 2018) and approximately 150,000 jobs. Set nets consist of netting panels hanging in the water column, where they are held perpendicular to the bottom by floaters and sinkers. Bottom-set fixed nets passively exploit the movements of target species (Gabriel et al., 2005). The fish swimming into them are caught by being gilled, tangled or wedged in gillnets, which are constituted of a single netting panel. On the contrary, the typical catching method of trammel nets is trapping the fish in a pocket of netting thanks to three panels: an inner panel with small mesh size and two outer panels with larger mesh size (Fabi et al., 2002). The success of the passive nets is due to their ease of use and handling (especially on small boats) (Dinçer \& Bahar, 2008), high selectivity (especially gillnets) (Holt, 1963; Fabi et al., 2002) and their high capture efficiency for numerous commercial species (Amengual-Ramis et al., 2016). Their technical parameters, e.g. mesh size, netting twine, hanging ratio and net drop, vary widely in relation to the characteristics of target species and fishing areas (e.g. depth, seafloor), as do their selection properties (Stergiou et al., 2006; Lucchetti et al., 2017a). Although passive nets are considered as selective gears, they nonetheless produce a large amount of discards (Goncalves et al., 2007; Tzanatos \& Somarakis, 2007) that range from 5\% to about $40 \%$ of the total biomass caught (Tsagarakis, Palialexis \& Vassilopoulou, 2014). SSFs discards consist of species with low commercial value, individuals that are found in poor condition and specimens under the Minimum Conservation Reference Size (MCRS; Regulation (EU), 2019/1241). The proportion of undersized individuals in the catch is variable and for some commercial species it can be quite high (20\% for Sparus aurata, 28.2-74.8\% for Diplodus spp., 93.8\% for Pagellus acarne in the eastern Mediterranean, Tzanatos et al., 2008; large numbers of Diplodus bellottii, Argyrosomus regius in Cadiz and Diplodus spp., Pagrus pagrus in the Cyclades, Goncalves et al, 2007). Notably, species that are caught in excessively small amounts for the fishers' target market may also become discards (Goncalves et al., 2007). Moreover, set nets can be also responsible for the incidental catch of protected species such as sea turtles (Lucchetti and Sala, 2010; Casale, 2011; Lucchetti et al., 2017b) and elasmobranches with no economic value (Morey et al., 2006; Saidi et al., 2016; Bradai, Saidi \& Enajjar, 2018)

The reduction of discards and bycatch has become a priority for fisheries worldwide, by means of measures to improve selectivity and to preserve the environment (FAO, 2011). The Common Fishery Policy, through the article 15 of Regulation (EU), 2013/1380, calls for the development of more selective technical solutions, to avoid the catch of unwanted species and sizes. Several solutions are being tested in the Mediterranean. They include: i) gear modifications to improve size and species selection (Lucchetti et al., 2015, 2017a); ii) time/area fishing closures to minimize bycatch (Lucchetti, Vasapollo \& Virgili, 2017a); iii) mitigation devices to avoid catching some protected species (e.g. UV lights for sea turtles; Virgili et al., 2017); and iv) alternative and more sustainable fishing gears (Amengual-Ramis et al., 2016).

Peer) reviewing PDF | (2019:12:43940:3:0:NEW 6 May 2020) 
As regards the latter point, experimental pots developed in the past few years in certain areas have ensured catch efficiencies comparable to those of traditional set nets (Furevik \& Hågensen, 1997; Iskandar et al., 2006; Furevik et al., 2008; Königson et al., 2015; Amengual-Ramis et al., 2016). Pots are passive gears to which fish, crustaceans and molluscs are attracted by bait or pasture, whereas cephalopods are caught because use them as a refuge or a site to spawn. Pots have several appealing features - in particular a minimal habitat impact and low manufacturing cost - which have led them to be classified as LIFE (low-impact fuel-efficient) gears (Suuronen et al., 2012). Moreover, bycatch can be minimized by acting on bait, mesh size, materials, and position/design of the entrance and the escape gap(s) (Furevik \& Løkkeborg, 1994; Furevik \& Hågensen, 1997; Boutson et al., 2009).

In Mediterranean SSFs traditional pots are locally employed to target molluscs and crustaceans (Grati et al., 2010; Amengueal-Ramis et al., 2016), ensuring high catch efficiency and low discard rates (0.8-6.6\%; Fabi et al., 2001). They are usually deployed in specific seasons (e.g. the spawning period of Sepia officinalis, Melli et al., 2014), in circumscribed areas (e.g. north western Adriatic Sea for Squilla mantis, Grati et al., 2018; Gulf of Càdiz (Spain), Thracian Sea (Greece) and Gulf of Gabès (Tunisia) for Octopus vulgaris, Ezzeddine-Najai, 1992; Tsangridis, Sánchez \& Ioannidou, 2002; Sobrino et al., 2011), or in replacement of other gears (e.g. for Nephrops norvegicus during trawl fishing closures in Croatian northern Adriatic waters, Brčić et al., 2018). A major disadvantage of traditional pots is their large volume, which entails that vessels can carry only a limited number of units per trip. In the Mediterranean Sea, studies of alternative fishing gears such as innovative pots are still limited (ICES SGPOT, 2008, 2009; Pol et al., 2010) and mainly regard those targeted to cephalopods like $O$. vulgaris (Sbrana et al., 2008) and crustaceans such as $N$. norvegicus, Plesionika spp. (Colloca, 2002; Sartor et al., 2006) and Palinurus elephas (Amengual-Ramis et al., 2016).

Based on these considerations, a pilot study was devised to test a fully collapsible pot design and to compare it to a traditional set net in commercial fishing conditions. The main goals of the study were to evaluate the respective catch compositions and to assess the effectiveness of the pots in terms of their use and handling, discards and bycatch reduction.

\section{Materials \& Methods}

\section{Study area}

The pilot study was conducted in FAO Geographical Sub-Area 17 (north-western Adriatic Sea) and involved three coastal areas (Marina di Ravenna, Portonovo and Senigallia), where depth ranges from 5 to $19 \mathrm{~m}$ (Figure 1). Specifications of bottom type and average depth of the three sites are listed in Table 1. In these areas, SSFs mostly employ gillnets and trammel nets to catch cuttlefish (S. officinalis), various fish species (e.g. Solea solea, Lithognathus mormyrus, Diplodus spp., S. aurata, Sciaena umbra, Umbrina cirrhosa, Dicentrarchus labrax) and crustaceans (S. mantis, Paeneus kerathurus) (Fabi \& Grati, 2005). Moreover, artisanal pots are deployed in spring to specifically target cuttlefish. 
119 Fishing gears and experimental setup

120 The trials were conducted on board local professional fishing vessels (Table 1). The

121 characteristics of the traditional trammel nets (GTRs) employed and the fishing grounds were

122 selected by the fishers, and similarly the fishing operations (e.g. fishing time) and the sorting of

123 the catch were carried out following the fishers' procedures, without interferences from the

124 scientists on board. Experiments to compare the GTRs and the foldable pots were carried out

125 from April to August, in 2016 and 2017, and involved a total number of 42 fishing trials: 20 at

126 Marina di Ravenna, 12 at Portonovo and 10 at Senigallia. To minimize differences due to patchy

127 species distribution, GTRs and pots were deployed close to each other (a few tens of metres).

128 The technical features of the GTRs are reported in Figure 2. The three netting panels were made

129 of transparent polyamide multifilament: $210 / 4 \mathrm{~mm}$ multifilament and $36 \mathrm{~mm}$ mesh bar for the

130 inner panel and 210/3 mm multifilament and $200 \mathrm{~mm}$ mesh bar for the outer panels. The net had

131 a nominal height of $2.5 \mathrm{~m}$ (35 meshes), although its effective vertical opening in the water was

132 around $1.5 \mathrm{~m}$. The float line and lead line were in propylene (diameter, 8 and $10 \mathrm{~mm}$,

133 respectively); the float line was reinforced with external oval-shaped floats (diameter, $8 \mathrm{~cm}$ ); the

134 lead line weighed $120 \mathrm{~g} / \mathrm{m}$. The total length of the set nets used in each site was: $500 \mathrm{~m}$ at

135 Marina di Ravenna and Portonovo, $300 \mathrm{~m}$ at Senigallia (Table 1). The GTRs were set early in the

136 morning and hauled in the afternoon.

137 The pots (manufactured by Trapula ${ }^{\text {LTD }}$, Croatia; Figure 3) have a stainless-steel bar frame with a

138 pentagonal shape and a single oval entrance. Two steel structures on the top and bottom allow

139 folding them. A propylene rope $5 \mathrm{~mm}$ in diameter was externally reinforced with a nylon net (32

$140 \mathrm{~mm}$ square-mesh bar). Flexible steel bars $2 \mathrm{~mm}$ in diameter allow manual adjustment of the

141 opening. To establish whether catch efficiency was related to the volume of the chamber

142 (Furevik \& Løkkeborg, 1994), two different pot sizes were tested: a smaller pot (SP) measuring

$14340 \times 100 \mathrm{~cm}$ (height $\mathrm{x}$ width) and a larger pot (LP) measuring $60 \times 140 \mathrm{~cm}$. The pots were

144 attached to a main propylene line (namely a gang) $8 \mathrm{~mm}$ in diameter anchored to the seabed by 2

$145 \mathrm{~m}$ plastic branch lines $5 \mathrm{~mm}$ in diameter, placed at $15 \mathrm{~m}$ intervals. The pots were set $15 \mathrm{~m}$ apart

146 according to the traditional rigging used by the local fishers (Fabi et al., 2001). The number of

147 pots of each type ranged from 9 to 20 per fishing trial. Soaking time (i.e. the period of time the

148 pots were left on the bottom) depended on weather conditions and fishers' tactics (Table 1). They

149 were commonly retrieved after 2-3 days, or more, in case of adverse weather conditions, to

150 attract a wider range of commercial species other than cuttlefish, for which traditional pots are

151 usually left 24 hours (Fabi, 2001). The pots were not baited, but several black plastic ribbons

152 were attached to the frame, to attract cuttlefish.

153 The GTR and pot hauls were paired: each haul consisted in setting and retrieving the GTR, the

154 gang with SPs and the gang with LPs.

155 Data collection

156 For each haul, the crew sorted onboard the catch, that was kept separate by gear (GTR, LP, SP).

157 The total catch for each gear was thus divided into a landed catch (species with commercial

158 value, not necessarily target species) and discards, i.e. species discarded for different reasons 
159 (invertebrates and fish species with no commercial value, commercial individuals under the

160

161

162

163

164

165

166

167

168

169

170

171

172

173

174

175

176

177

178

179

180

181

182

183

184

185

186

187

188

189

190

191

192

193

194

195

196

197

MCRS or in poor conditions). All individuals were identified to the lowest taxonomic level possible, counted, weighed to the lowest $0.1 \mathrm{~g}$ and measured to the nearest $0.5 \mathrm{~cm}$ for total length (TL; fish) or mantle length (ML; cephalopods) and to the nearest $0.5 \mathrm{~mm}$ for carapace length (CL; crustaceans).

\section{Data analysis}

The catch per unit effort (CPUE) was calculated for GTRs and pots. The GTR catch was standardized for the number of individuals $\left(\mathrm{CPUE}_{I}\right)$ and total catch weight $\left(\mathrm{CPUE}_{W}\right.$; in $\left.\mathrm{kg}\right)$ captured by $1000 \mathrm{~m}$ of net in $12 \mathrm{~h}$, considering that fishers commonly set 3000 to $6000 \mathrm{~m}$ of net and haul it up after about half a day. The pot catch was standardized for the $\mathrm{CPUE}_{I}$ and $\mathrm{CPUE}_{W}$ (in $\mathrm{kg}$ ) captured by 66.6 pots (i.e., the number of pots corresponded to $1000 \mathrm{~m}$ of set net considering $15 \mathrm{~m}$ distance between two subsequent pots, according to Fabi et al., 2001) in $24 \mathrm{~h}$. This duration corresponds to the commercial fishing time of the traditional pots used in the area to target cuttlefish (Fabi, 2001). The Kruskal-Wallis H test $\left(\chi^{2}\right)$ was applied to seek differences between the $\mathrm{CPUE}_{W}$ of GTRs and pots. A non parametric test was adopted, because the data distributions were not normal and extremely skewed, with wide tails. If differences did emerge, a pairwise Wilcoxson's signed rank test based on Bonferroni correction for multiple comparisons was applied to establish the levels showing significantly different median values.

Differences in the size of the individuals caught by the GTRs, LPs and SPs were explored by analysing the length frequency distribution (LFD) of the landed species. The catch efficiency of each pot type vs GTR was compared using generalized linear mixed models (GLMMs; Holst and Revill, 2009). The probability for an individual to be retained in a pot follows from:

$$
\operatorname{Pr}\left\{{ }^{\text {Pot }} /(\text { Pot }+ \text { GTR })\right\}=1 /\left(1+e^{-\left(\beta_{0}+\beta_{1} \times \text { length }+\beta_{2} \times \text { length }^{2}+\beta_{3} \times \text { length }^{3}\right)}\right)
$$

A binomial error distribution was used to calculate the probability of the number of fish caught in a pot $\left(\mathrm{CPUE}_{I}\right)$ given that they were caught by both gears based on 1-cm size classes. A probability value of 0.5 corresponds to equal catches in both gears. According to Holst and Revill (2009), a $3^{\text {rd }}$ order polynomial would be adequate for most cases, although in some instances a $1^{\text {st }}$ or $2^{\text {nd }}$ order would be enough. The best binomial model was chosen based on the lowest Akaike's Information Criterion (AIC) value. A random term was added to the models. Since the GTR and pot hauls were paired, the catches for each site and for each gear were pooled and the term 'site' was used as a random intercept.

The most abundantly caught species, S. officinalis and Diplodus annularis, were selected for the catch comparison analysis. Since only SPs were set at Portonovo, the catch comparison of LPs included only the Senigallia and Marina di Ravenna. The models are illustrated graphically with a $95 \%$ confidence interval (CI) calculated with a bootstrap method using 999 simulations. The free software R (R Core Team, 2018) and the R packages nlme (Pinheiro et al., 2018) and lme4 (Bates et al., 2014) were used for the analyses.

\section{Results}


198 Overall, the three gears caught 53 species, 38 of which belonged to the landed fraction 199 (GTRs $=30, \mathrm{LPs}=15$, and $\mathrm{SPs}=22$ ) and 28 to the discard species (GTRs $=25, \mathrm{LPs}=5$, and $\mathrm{SPs}=5)$, 200 thus confirming that the pots were more species-selective than GTRs (Supplementary Tables 1 201 and 2).

202 As regards the landed species, cuttlefish (S. officinalis) was the most abundant in terms of 203 biomass at all 3 sites for all 3 gears. Two other abundant species caught by all 3 gears were

204

205

206

207

208

209

210

211

212

213

214

215

216

217

218

219

220

221

222

223

224

225

226

227

228

229

230

231

232

233

234

235

236

237 annular seabream (D. annularis), caught at Marina di Ravenna and Senigallia but not at Portonovo, and striped seabream (L. mormyrus), caught at all 3 sites with greater abundance at Senigallia and Portonovo. Additional landed species caught by GTRs were S. solea, S. mantis and S. umbra at Marina di Ravenna; Liza aurata, Sarda sarda and Scophthalmus rhombus at Senigallia; and Mugil cephalus at Portonovo. Other landed species caught by the pots were $S$. umbra (LP, SP) and Conger conger (LP) at Marina di Ravenna and Dentex dentex (SP) at Portonovo (Supplementary Table 1).

The mean biomass values (calculated as CPUEw) and 95\% CIs of the landed catch are reported in Table 2. The CI values of the three gears did overlap, indicating the lack of significant differences among them, both at each site and as a whole. Standardization of the landed catch weight failed to highlight significant differences in the medians among GTRs, LPs and SPs, either within the 3 sites or as a whole $\left(\chi^{2}=2.59, \mathrm{df}=2, \mathrm{p}=0.274\right.$; Figure 4).

The discards of LPs and SPs were lower than those of the GTRs both in terms of species number and of $\mathrm{CPUE}_{\mathrm{w}}$; in fact, they were close to zero both at Senigallia and at Portonovo (Supplementary Table 2). The GTRs captured large amounts of Alosa fallax and Pteroplatytrygon violacea at Marina di Ravenna; A. fallax and Liocarcinus vernalis at Senigallia and Eriphia verrucosa, Hexaplex trunculus and Maja crispata at Portonovo (Supplementary Table 2).

The CIs of the mean biomass values (CPUEw) of GTR discards did not overlap with those of LPs and SPs, whereas those of LPs and SPs did (Table 2). The discards showed significant differences in terms of standardized biomass $\left(\chi^{2}=11.34, \mathrm{df}=2, \mathrm{p}=0.004\right.$, Figure 4$)$ and were mostly caught by GTRs. Wilcoxson's pairwise test showed that the median differences between gears were significant for GTRs vs LPs and for GTRs vs SPs ( $p=0.011$ and $p=0.016$, respectively), whereas the medians of LPs and SPs were not significantly different. The LFD of $S$. officinalis and D. annularis at each site and as a whole is reported in Figure 5. The lines of LPs and SPs were mostly above those of GTRs, indicating a greater catch efficiency. The catch comparison curves (Figure 6 and Table 3) demonstrate that for S. officinalis, pots (both dimensions) were more efficient than GTRs. SPs were more efficient than GTRs for most S. officinalis sizes, except for the larger ones (above the $25 \mathrm{~cm}$ size class), for which the efficiency of both gears were similar, as the lower CI exceeds the limit of 0.5 indicating equal proportion of individual catches between both gears. In contrast, LPs showed the same efficiency as GTRs for the smaller individuals (below the $11 \mathrm{~cm}$ size class) and were more efficient for the larger individuals. LPs and SPs showed overlapping CIs from the $10 \mathrm{~cm}$ size class, i.e. a similar catch efficiency. As regards $D$. annularis, the GTR reflected a greater efficiency than both LPs 
238

239

240

241

242

243

244

245

246

247

248

249

250

251

252

253

254

255

256

257

258

259

260

261

262

263

264

265

266

267

268

269

270

271

272

273

274

275

276

277

and SPs at the smaller sizes, usually under the MCRS of the species $(12 \mathrm{~cm})$. As a result, the percentage in number of undersized individuals of $D$. annularis caught by GTR was $15.1 \%$ (7.1\% for Marina di Ravenna; $16.4 \%$ for Senigallia), while it was lower for both pots: $7.3 \%$ for SPs (3.3\% for Marina di Ravenna; $8 \%$ for Senigallia) and 3.7\% for LPs (3.3\% for Marina di Ravenna; $4.5 \%$ for Senigallia). Therefore, LPs and SPs both showed a high selectivity for larger fish, although they also caught some undersized individuals. However, there were no differences among the three gears in the catch efficiency for the larger $D$. annularis individuals.

\section{Discussion}

This study was aimed at testing the catching efficiency of an innovative pot design in the northwestern Adriatic Sea; in particular, it was evaluated the pot's ability to provide an alternative to traditional trammel nets and to reduce discards in SSFs. The comparison implied a different standardization $\left(\mathrm{CPUE}_{\mathrm{w}}\right.$ at 12 hours for trammel nets and 24 hours for pots) that represented a compromise to maintain the standardization unit as close as possible between the two gears, taking into account that they operate in different ways and with a different fishing time. The main finding, from the catch comparison analysis of the two most abundant species caught (cuttlefish and annular sea bream), was that the catch rates of the two types of pot tested, which differed only in dimensions, were comparable to those of the trammel nets. These data are in line with the high efficiency of the experimental pots reported in the Barents Sea (Furevik et al., 2008) and the Baltic Sea (Königson et al., 2015), where pots showed similar, if not higher, catch rates than those of passive nets, at least in a period of the year. Interestingly, the innovative pots caught a larger number of commercial species than the traditional ones used in the area by artisanal fishers, which are not collapsible, with a different shape and entrance, and mainly target cuttlefish (Fabi et al., 2001).

Regarding the annular sea bream, the poor selectivity of the trammel nets found for this species has been previously reported for Diplodus spp. by Tzanatos et al. (2008), who estimated a percentage (in weight) of the undersized individuals caught of $28.2 \%$ for D. annularis and $74.8 \%$ for $D$. sargus, being even higher than the average percentage of this study (15\%). In contrast, pots seemed to be able to avoid D. annularis juveniles (average percentage of around 7\%). Unlike studies in other areas (Munro, 1974; Furevik \& Løkkeborg, 1994; Hedgärde et al., 2016), which concluded that larger pots are more effective than small ones, in this study, pot size seemed not to affect catch efficiency. However, the number of pots that actually produced a catch, ranged between $38.5 \pm 3.3 \%$ for SPs to $42.5 \pm 4.3 \%$ for LPs, stressing the need for increasing catch efficiency by using attractive baits.

The cost of a collapsible pot as the one tested in this study ranges from $€ 50$ (SP) to $€ 100$ (LP), whereas $100 \mathrm{~m}$ of the traditional trammel net used for the sea trials is around $€ 200$. Assumed that $100 \mathrm{~m}$ of nets would correspond to more than 6 pots (as stated in the Materials and Methods section), the alternative gear is more expensive. Nevertheless, whereas the set nets usually last a single season and are then too damaged to be repaired, these kind of pots last up to two years. Another advantage of pots is that they afford a more limited access to the catch, making them 
278 less subject to depredation by large predators than set nets (e.g. seal- and dolphin-safe fishing 279 gear; Königson, 2011; Königson et al., 2015). Moreover, they provide a greater catch quality, 280 because they generally do not damage the specimens caught (Suuronen et al., 2012; Olsen, 281 2014). In addition, even if trammel nets require a shorter fishing time than pots, fishers could set 282 different pots gangs in order to alternate the retrieve, and thus to haul them daily.

283 With reference to discards, the greater amount caught by the trammel nets clearly produces a 284 greater impact on the benthic community, since discard mortality is high (Suuronen et al., 2012). 285 Moreover, the cleaning of the trammel net implies an additional time and labour on deck for 286 fishers, since discards must be released or untangled manually (Sartor et al., 2018; Szynaka et al., 287 2018). In contrast, the removal of discards from pots can be done without significantly reducing

288

289

290

291

292

293

294

295

296

297

298

299

300

301

302

303

304

305

306

307

308

309

310

311

312

313

314

315

316

317 fishing time and leaving high probability for the unwanted organisms to survive (Suuronen et al., 2012). Discarding is a major issue for fisheries management worldwide (Tsagarakis, Palialexis \& Vassilopoulou, 2014). In the Mediterranean, the Common Fisheries Policy (CFP Regulation (EU), 2013/1380) has introduced the obligation to land ('discard ban') all the individuals of the species with minimum legal size (MCRS, e.g. those species reported in the Annex III of the Council Regulation (EC) No 1967/2006), thus emphasizing the need to reduce discards (Damalas, 2015). The landing obligation is a matter of concern among fishers, which are facing difficulties related to storing and bringing to land the former discard, due to limited hold space, and to sorting time or personnel increasing (Maynou et al., 2018). The introduction of a new and alternative technology in a fishery, such as innovative pots, could help to achieve this goal of discard reduction only if it is acceptable to both fishers and fishery policies. In this context, fish collapsible pots are revealed to be: practical (i.e. involving no major changes to common fishers' practices), cost-effective (i.e. easy to use and not expensive to maintain, no waste of time for cleaning the gear), efficient (i.e. large spectrum of species caught) and enforceable (i.e. easy to control by inspection authorities).

With reference to bycatch of sensitive and protected species, during our study the trammel nets caught five specimens of the pelagic stingrays (Pteroplatytrigon violacea), a frequent event in several Adriatic fisheries (Bonanomi et al., 2018). This Elasmobranch species, usually discarded due to its scarce commercial value, is considered as a 'Least Concern' species in the IUCN red list (Baum et al., 2016). Another bycatch species caught by the trammel nets was the twait shad (A. fallax), listed in Annexes II and V of the Habitats Directive (European Commission, 1992) as requiring close protection. In addition, the passive nets deployed in the central and northern Adriatic are responsible for the bycatch - maybe as many as thousands individuals a year (Lucchetti, Vasapollo \& Virgili, 2017b) - of loggerhead sea turtles (Caretta caretta), which are listed in Annex IV of the Habitats Directive. In contrast, the pots did not capture any of these species, substantially due of the small size of the pot entrance compared with the larger size of animals such as stingrays and sea turtles. As regards A. fallax, its absence in the pots catch may depend on their position close to the bottom, whereas trammel nets can also intercept pelagic fish species (A. fallax, Sardina pilchardus, Engraulis encrasicolus, Scomber japonicus etc.) which for different reasons can be discarded (Goncalves et al., 2007). 


\section{Conclusions}

320

321

322

323

324

325

326

327

328

329

330

331

332

333

334

335

336

337

338

339

340

341

342

343

344

345

346

347

348

349

350

351

352

353

354

355

356

357

358

359

The innovative pots tested in this study seem to provide a sound alternative to the traditional trammel nets used in the Adriatic Sea, at least in spring and summer, as concerns the small-scale fishery targeting common cuttlefish. These pots do not require a different vessel rigging nor changes to the on board practices; moreover, they can be used without baits and their foldable design involves that they can be easily stored on board the typical artisanal boats used in Mediterranean SSFs. The findings of this pilot study, although not conclusive, clearly indicate that these alternative gears go some way towards reducing bycatch and discards in SSFs while maintaining the commercial catch. Similar tests should be extended to other areas and seasons, also using baits, to provide a clearer assessment of their efficiency.

\section{Acknowledgements}

This study was authorized by the Italian Coast Guard. It was conducted with the contribution of the LIFE financial instrument of the European Community, TartaLife Project - Reduction of sea turtle mortality in professional fishing (LIFE12NAT/IT/000937). It does not necessarily reflect the European Commission's views and in no way anticipates future policy. This work was finalised under the project "Innovative technologies and sustainable use of fisheries and biological resources in the Mediterranean sea" (FISHMED-PHD). We are indebted to the personnel of CNR-IRBIM (Ancona) and CESTHA (Marina di Ravenna), to the crew of FVs Jessica (Portonovo), Zio Lino (Senigallia) and Nemo (Marina di Ravenna) for their help in fieldwork. We are grateful to Word Designs for the language revision (www.silviamodena.com).

\section{References}

Amengual-Ramis JF., Vázquez-Archdale M., Cánovas-Pèrez C., Morales-Nin B. 2016. The artisanal fishery of the spiny lobster Palinurus elephas in Cabrera National Park, Spain: Comparative study on traditional and modern traps with trammel nets. Fisheries Research 179:23-32. DOI: 10.1016/j.fishres.2016.01.02.

Bates D., Mächler M., Bolker B., Walker S. 2014. Fitting linear mixed-effects models using Ime4. arXiv preprint arXiv:1406.5823.

Baum J., Bianchi I., Domingo A., Ebert DA., Grubbs RD., Mancusi C., Piercy A., Serena F., Snelson FF. 2016. Pteroplatytrygon violacea. The IUCN Red List of Threatened Species.

Bonanomi S., Pulcinella J., Fortuna CM., Moro F., Sala A. 2018. Elasmobranch bycatch in the Italian Adriatic pelagic trawl fishery. PLOS ONE. DOI: https://doi.org/10.1371/journal.pone.0191647.

Boutson A., Mahasawasde ÆC., Mahasawasde S., Tunkijjanukij ÆS. 2009. Use of escape vents to improve size and species selectivity of collapsible pot for blue swimming crab Portunus pelagicus in Thailand. Fisheries Science:25-33. DOI: 10.1007/s12562-008-0010-z.

Bradai MN., Saidi B., Enajjar S. 2018. Overview on Mediterranean Shark's Fisheries: Impact on the Biodiversity. Marine ecology: Biotic and abiotic interactions:211-230.

Brčić J., Herrmann B., Ma M., Baranovi M., Krstulovi S., Frane Š. 2018. Size selection of Nephrops norvegicus ( L .) in commercial creel fi shery in the Mediterranean Sea. Fisheries 
360

361

362

363

364

365

366

367

368

369

370

371

372

373

374

375

376

377

378

379

380

381

382

383

384

385

386

387

388

389

390

391

392

393

394

395

396

397

398

399

400

401

402

403

404

405

Research 200:25-32. DOI: 10.1016/j.fishres.2017.12.006.

Colloca F. 2002. Life cycle of the deep-water pandalid shrimp Plesionika edwardsii (Decapoda, Caridea) in the central Mediterranean sea. Journal of Crustacean Biology 22:775-783. DOI: 10.1651/0278-0372(2002)022.

Damalas D. 2015. Mission impossible : Discard management plans for the EU Mediterranean fisheries under the reformed Common Fisheries Policy. Fisheries Research 165:96-99. DOI: 10.1016/j.fishres.2015.01.006.

Dinçer AC., Bahar M. 2008. Multifilament Gillnet Selectivity for the Red Mullet (Mullus barbatus) in the Eastern Black Sea Coast of Turkey, Trabzon. Turkish Journal of Fisheries and Aquatic Sciences 359:355-359.

Directive H. 1992. Council Directive 92/43/EEC of 21 May 1992 on the conservation of natural habitats and of wild fauna and flora. Official Journal of the European Union 206:7-50.

Ezzeddine-Najai S. 1992. Biologie et pêche du poulpe Octopus vulgaris Cuvier, 1797 (Cephalopoda, Octopoda) du golfe de Gabès. Bulletin de l'Institut National des Sciences et Technologies Océanographiques et de Pêche à Salammbô 19:5-19.

Fabi G. 2001. Sepia officinalis: impact of three set of fishing techniques in the Adriatic and the Ligurian Sea. Study contract No. 98/069. :119.

Fabi G., Grati F. 2005. Small-scale fisheries in the maritime department of Ancona (Central Northern Adriatic Sea). AdriaMed Tech:64-84.

Fabi G., Grati F., Lucchetti A., Scarcella G. 2001. Osservazioni preliminari sulle catture di Sepia officinalis con tre attrezzi da posta in Medio Adriatico. Biologia Marina Mediterranea 8:660-664.

Fabi G., Sbrana M., Biagi F., Grati F., Leonori I., Sartor P. 2002. Trammel net and gill net selectivity for Lithognathus mormyrus (L., 1758), Diplodus annularis (L., 1758) and Mullus barbatus (L., 1758) in the Adriatic and Ligurian seas. Fisheries Research 54:375-388.

FAO. 2011. International Guidelines on bycatch management and reduction of discards. Rome.

FAO. 2018. The state of Mediterranean and Black Sea fisheries 2018.

Furevik DM., Hågensen SP. 1997. Experiments with cod pots as an alternative to gill-nets in the Varanger fjord in April-June and October-December 1996. Proceedings of the 7th Russian/Norwegian Symposium: Gear Selection and Sampling Gears:121-132.

Furevik DM., Humborstad O., Jørgensen T., Løkkeborg S. 2008. Floated fish pot eliminates bycatch of red king crab and maintains target catch of cod. Fisheries Research 92:23-27. DOI: 10.1016/j.fishres.2007.12.017.

Furevik DM., Løkkeborg S. 1994. Fishing trials in Norway for torsk (Brosme brosme) and cod (Gadus morhua) using baited commercial pots. Fisheries research 19:219-229.

Gabriel O., Lange K., Dahm E., Wendt T. 2005. Von Brandt's Fish Catching Methods of the World. Blackwell Publishing.

Goncalves J., Stergiou KI., Hernando JA., Puente E., Moutopoulos DK., Arregi L., Soriguer MC., Vilas C., Coelho R., Erzini K. 2007. Discards from experimental trammel nets in southern European small-scale fisheries. 88:5-14. DOI: 10.1016/j.fishres.2007.06.017.

Grati F., Fabi G., Azzurro E. 2018. Seasonal dynamics of small-scale fisheries in the Adriatic Sea. DOI: $10.12681 / \mathrm{mms} .2153$.

Grati F., Polidori P., Scarcella G., Fabi G. 2010. Estimation of basket trap selectivity for changeable nassa ( Nassarius mutabilis ) in the Adriatic Sea. Fisheries Research 101:100107. DOI: 10.1016/j.fishres.2009.09.012.

Hedgärde M., Berg CW., Kindt-Larsen L., Lunneryd SG., Königson S. 2016. Explaining the

Peer) reviewing PDF | (2019:12:43940:3:0:NEW 6 May 2020) 
406

407

408

409

410

411

412

413

414

415

416

417

418

419

420

421

422

423

424

425

426

427

428

429

430

431

432

433

434

435

436

437

438

439

440

441

442

443

444

445

446

447

448

449

450

451

catch efficiency of different cod pots using underwater video to observe cod entry and exit behaviour. The Journal of Ocean Technology 11:67-90.

Holst R., Revill A. 2009. A simple statistical method for catch comparison studies. Fisheries Research 95:254-259. DOI: 10.1016/j.fishres.2008.09.027.

Holt SJ. 1963. A method for determining gear selectivity and its application. ICNAF Spec. Publ. 5:106-115.

ICES. 2009. ICES SGPOT REPORT 2009 Report of the Study Group on the Development of Fish Pots for Commercial Fisheries and Survey Purposes T. In: Ancona, 19-20.

ICES SGPOT REPORT 2008 Report of the Study Group on the Development of Fish Pots for Commercial Fisheries and Survey Purposes 2008. Tórshavn, Faroe Islands.

Iskandar D., Suzuki Y., Shiode D., Hu F., Tokai T. 2006. Catchability difference of gill net and collapsible baited pot for Japanese rock crab. Indian Journal of Fisheries 12:107-112.

Königson S. 2011. Seals and fisheries: A study of the conflict and some possible solutions. Department of Marine Ecology; Institutionen för marin ekologi.

Königson SJ., Fredriksson RE., Lunneryd S-G., Strömberg P., Bergström UM. 2015. Cod pots in a Baltic fishery: are they efficient and what affects their efficiency? ICES Journal of Marine Science 72:1545-1554.

Lucchetti A., Buglioni G., Conides A., Klaoudatos D., Sartor P., Sbrana M., SPEDICATO M-T., Stamatopoulos C. 2015. Technical measures without enforcement tools: is there any sense? A methodological approach for the estimation of passive net length in small scale fisheries. Mediterranean Marine Science 16:82-89.

Lucchetti A., Carbonara P., Colloca F., Lanteri L., Teresa M., Sartor P. 2017. Ocean \& Coastal Management Small-scale driftnets in the Mediterranean: Technical features, legal constraints and management options for the reduction of protected species bycatch. Ocean and Coastal Management 135:43-55. DOI: 10.1016/j.ocecoaman.2016.11.002.

Lucchetti A., Sala A. 2010. An overview of loggerhead sea turtle (Caretta caretta) bycatch and technical mitigation measures in the Mediterranean Sea. Reviews in Fish Biology and Fisheries 20:141-161.

Lucchetti A., Vasapollo C., Virgili M. 2017a. Sea turtles bycatch in the Adriatic Sea set net fisheries and possible hot - spot identification. Aquatic Conservation: Marine and Freshwater Ecosystems:1-10. DOI: 10.1002/aqc.2787.

Lucchetti A., Vasapollo C., Virgili M. 2017b. An interview-based approach to assess sea turtle bycatch in Italian waters. PeerJ 5:e3151.

Maynou F., del Mar Gil M., Vitale S., Giusto GB., Foutsi A., Rangel M., Rainha R., Erzini K., Gonçalves JMS., Bentes L. 2018. Fishers' perceptions of the European Union discards ban: perspective from south European fisheries. Marine Policy 89:147-153.

Melli V., Riginella E., Nalon M., Mazzoldi C. 2014. From Trap to Nursery . Mitigating the Impact of an Artisanal Fishery on Cuttlefish Offspring. PLOS ONE 9. DOI: 10.1371/journal.pone.0090542.

Morey G., Moranta J., Riera F., Grau AM., Morales-Nin B. 2006. Elasmobranchs in trammel net fishery associated to marine reserves in the Balearic Islands (NW Mediterranean). Cybium 30:125-132.

Munro JL. 1974. The mode of operation of Antillean fish traps and the relationships between ingress, escapement, catch and soak. ICES Journal of Marine Science 35:337-350.

Olsen L. 2014. Baited pots as an alternative fishing gear in the Norwegian fishery for Atlantic cod (Gadus morhua). The Artic University of Norway.

Peer] reviewing PDF | (2019:12:43940:3:0:NEW 6 May 2020) 
452 Pinheiro J., Bates D., DebRoy S., Sarkar D. 2018. R Core Team (2018). nlme: Linear and

453

454

455

456

457

458

459

460

461

462

463

464

465

466

467

468

469

470

471

472

473

474

475

476

477

478

479

480

481

482

483

484

485

486

487

488

489

490

491

492

493

494

495

496

497 nonlinear mixed effects models. R package version 3.1-137.

Pol MV., He P., Winger PD. 2010. Proceedings of the International Technical Workshop on Gadoid Capture by Pots (GACAPOT). Massachusetts Division of Marine Fisheries Technical Report 40:107.

R Core Team. 2018. R: A language and environment for statistical computing. R Foundation for Statistical Computing, Vienna, Austria. 2012. URL http://www. R-project. org.

Regulation (EU). 2013. No. 1380/2013 of the European Parliament and of the Council of 11 December 2013 on the Common Fisheries Policy, amending Council Regulations (EC) No 1954/2003 and (EC) No 1224/2009 and repealing Council Regulations (EC) No 2. :22-61.

Regulation (EU). 2019. Regulation (EU) 2019/1241 of the European Parliament and of the Council of 20 June 2019 on the conservation of fisheries resources and the protection of marine ecosystems through technical measures. :97.

Saidi B., Enajjar S., Bradai MN. 2016. Elasmobranch captures in shrimps trammel net fishery off the Gulf of Gabès (Southern Tunisia, Mediterranean Sea). Journal of Applied Ichthyology 32:421-426. DOI: 10.1111/jai.13061.

Sartor P., Rossetti I., Vannucci A., Viva C. 2006. Pesca del gobbetto striato, Plesionika edwardsii (brandt, 1851), con nasse sperimentali nel Tirreno settentrionale. Biologia Marina Mediterranea 13:288-289.

Sartor P., Veli DL., Carlo F De., Ligas A., Massaro A., Musumeci C., Sartini M., Rossetti I., Sbrana M., Viva C. 2018. Reducing unwanted catches of trammel nets : experimental results of the " guarding net" in the caramote prawn, Penaeus kerathurus, small-scale fishery of the Ligurian Sea ( western Mediterranean ). :131-140.

Sbrana M., Rossetti I., Sartor P., Vannucci A., De Ranieri S. 2008. Sperimentazione di differenti tipologie di trappole per la pesca del polpo Octopus vulgaris (Cuvier 1797) nel Mar Ligure orientale. Biologia Marina Mediterranea 15:356-357.

Sobrino I., Juarez A., Rey J., Romero Z., Baro J. 2011. Description of the clay pot fishery in the Gulf of Cadiz ( SW Spain ) for Octopus vulgaris : Selectivity and exploitation pattern. Fisheries Research 108:283-290. DOI: 10.1016/j.fishres.2010.12.022.

Stergiou KI., Moutopoulos DK., Soriguer MC., Puente E., Lino PG., Zabala C., Monteiro P., Errazkin LA., Erzini K. 2006. Trammel net catch species composition, catch rates and mètiers in southern European waters : A multivariate approach. Fisheries Research 79:170 182. DOI: 10.1016/j.fishres.2006.03.003.

Suuronen P., Chopin F., Glass C., Løkkeborg S., Matsushita Y., Queirolo D., Rihan D. 2012. Low impact and fuel efficient fishing - Looking beyond the horizon. Fisheries Research 119-120:135-146. DOI: 10.1016/j.fishres.2011.12.009.

Szynaka MJ., Bentes L., Monteiro P., Rangel M., Erzini K. 2018. Reduction of by-catch and discards in the Algarve small-scale coastal fishery using a monofilament trammel net rigged with a guarding net. Scientia Marina:121-129.

Tsagarakis K., Palialexis A., Vassilopoulou V. 2014. Mediterranean fishery discards: review of the existing knowledge. ICES Journal of Marine Science 71:1219-1234. DOI: 10.4135/9781412953924.n678.

Tsangridis A., Sánchez P., Ioannidou D. 2002. Exploitation patterns of Octopus vulgaris in two Mediterranean areas. Scientia Marina 66:59-68.

Tzanatos E., Somarakis S. 2007. Discarding practices in a Mediterranean small-scale fishing fleet (Patraikos Gulf, Greece). Fisheries Management and Ecology:277-285. DOI: 
498

499

500

501

502

503

504

505

506

507 10.1111/j.1365-2400.2007.00556.x.

Tzanatos E., Somarakis S., Tserpes G., Koutsikopoulos C. 2008. Catch length analysis , relation to minimum landing sizes and management implications from a Mediterranean small-scale fishery ( Patraikos Gulf, Greece ). Fisheries Research 93:125-134. DOI: 10.1016/j.fishres.2008.03.003.

Virgili M., Vasapollo C., Lucchetti A. 2017. Can ultraviolet illumination reduce sea turtle bycatch in Mediterranean set net fisheries? Can ultraviolet illumination reduce sea turtle bycatch in Mediterranean set net fi sheries? Fisheries Research 199:1-7. DOI: 10.1016/j.fishres.2017.11.012. 


\section{Table $\mathbf{1}$ (on next page)}

Summary of the fishing trials carried out at the three sites (Marina di Ravenna, Senigallia, Portonovo)

AVG: Average; SD: Standard Deviation; LOA: Length all out; GT: Gross tonnage; GTR: Trammel net; LP: Large pots; SP: Small pots. 
1 Table 1. Summary of the fishing trials carried out at the three sites (Marina di Ravenna, Senigallia, Portonovo).

2 AVG: Average; SD: Standard Deviation; LOA: Length all out; GT: Gross tonnage; GTR: Trammel net; LP: Large pots; SP:

3 Small pots.

\begin{tabular}{|c|c|c|c|}
\hline & Marina di Ravenna & Senigallia & Portonovo \\
\hline Bottom type & $\begin{array}{l}\text { sandy-mud with scattered } \\
\text { rocky outcrops }\end{array}$ & sandy-mud & rocky \\
\hline $\begin{array}{r}\text { AVG depth }[\mathrm{m}] \pm \\
\text { SD }\end{array}$ & $9.9 \pm 2.5$ & $10.7 \pm 0.43$ & $6.0 \pm 0.57$ \\
\hline $\begin{array}{r}\text { Vessel } \\
\text { characteristics }\end{array}$ & LOA $12.4 \mathrm{~m} ; 10 \mathrm{GT} ; 350 \mathrm{~kW}$ & LOA $12.4 \mathrm{~m} ; 6 \mathrm{GT} ; 130 \mathrm{~kW}$ & LOA $6.6 \mathrm{~m} ; 1 \mathrm{GT} ; 100 \mathrm{~kW}$ \\
\hline Study period & April-July 2017 & April-June 2016 & May-August 2016 \\
\hline No. of trials & 20 & 10 & 12 \\
\hline GTR length [m] & 500 & 300 & 500 \\
\hline No. of LPs & 20 & $9-10$ & 0 \\
\hline No. of SPs & 20 & $19-20$ & 20 \\
\hline $\begin{array}{r}\text { AVG GTR } \\
\text { soak time }[h] \pm \text { SD }\end{array}$ & $19.9 \pm 3.3$ & $17.4 \pm 2.0$ & $17.2 \pm 1.8$ \\
\hline $\begin{array}{r}\text { AVG LP } \\
\text { soak time }[\mathrm{h}] \pm \text { SD }\end{array}$ & $91.4 \pm 28.7$ & $73.9 \pm 9.1$ & - \\
\hline $\begin{array}{r}\text { AVG SP } \\
\text { soak time }[h] \pm \text { SD }\end{array}$ & $87.3 \pm 25.6$ & $76.6 \pm 10.1$ & $90.1 \pm 21.3$ \\
\hline
\end{tabular}

4 


\section{Table 2 (on next page)}

Mean biomass values (CPUE ${ }_{\mathrm{w}}$ ) with standard errors and confidence intervals, in brackets, of the landed catch and of discards for the three gears.

GTR (trammel net), LP (large pot) and SP (small pot), at each site (top) and as a whole (bottom). NA (not available). 
Table 2: Mean biomass values $\left(C P U E_{W}\right)$ with standard errors and confidence intervals, in brackets, of the landed catch and of discards for the three gears,

GTR (trammel net), LP (large pot) and SP (small pot), at each site (top) and as a whole (bottom). NA (not available).

\begin{tabular}{llccc}
\hline & Site & \multicolumn{1}{c}{ GTR } \\
CPUE $_{W}$ & LP & SP \\
& & & & CPUE $_{W}$ \\
\hline & & & & \\
Landed & & & & \\
catch & M. di Ravenna & $5.41 \pm 0.76(3.92-6.89)$ & $7.27 \pm 1.77(3.81-10.73)$ & $3.72 \pm 0.64(2.48-4.97)$ \\
& Senigallia & $4.34 \pm 0.14(2.16-6.52)$ & $2.41 \pm 0.35(0.23-4.59)$ & $3.08 \pm 0.17(2.20-3.97)$ \\
& Portonovo & $2.90 \pm 0.70(1.53-4.27)$ & - & $2.48 \pm 0.59(1.33-3.62)$
\end{tabular}

$\begin{array}{lllcc} & \text { M. di Ravenna } & 0.77 \pm 0.20(0.38-1.17) & 0.14 \pm 0.04(0.07-0.21) & 0.07 \pm 0.05(0.02-0.17) \\ \text { Discards } & \text { Senigallia } & 0.95 \pm 0.57(0.17-2.07) & - & 0.04 \pm 0.0(\mathrm{NA}) \\ & \text { Portonovo } & 1.52 \pm 0.79(0.02-3.06) & - & 0.06 \pm 0.0(\mathrm{NA})\end{array}$

\begin{tabular}{llc}
\hline & Gear & CPUE $_{W}$ \\
\hline Landed & GTR & $4.35 \pm 0.51(3.35-5.34)$ \\
catch & LP & $6.01 \pm 1.39(3.28-8.74)$ \\
& SP & $3.21 \pm 0.36(2.49-3.93)$ \\
\hline \multirow{3}{*}{ Discards } & GTR & $0.95 \pm 0.23(0.51-1.40)$ \\
& LP & $0.14 \pm 0.04(0.06-0.21)$ \\
& SP & $0.06 \pm 0.03(0.01-0.12)$ \\
\hline
\end{tabular}




\section{Table 3(on next page)}

Estimates of the parameters of the GLMM calculated for catch comparison

SE: standard error. GTR: Trammel net; LP: Large pots; SP: Small pots. 
1 Table 3. Estimates of the parameters of the GLMM calculated for catch comparison. SE: 2 standard error. GTR: Trammel net; LP: Large pots; SP: Small pots.

\begin{tabular}{|c|c|c|c|c|c|c|}
\hline Species & Model & & Parameter & Estimate & SE & $\mathrm{p}$ \\
\hline \multirow{5}{*}{ Sepia officinalis } & \multirow[t]{2}{*}{ Linear } & \multirow[t]{2}{*}{ LP vs GTR } & $\beta_{0}$ & -0.61 & 0.45 & 0.171 \\
\hline & & & $\beta_{1}$ & 0.08 & 0.03 & 0.009 \\
\hline & \multirow{3}{*}{ Quadratic } & \multirow{3}{*}{ SP vs GTR } & $\beta_{p}$ & 4.07 & 1.47 & 0.006 \\
\hline & & & $\beta_{1}$ & -0.46 & 0.20 & 0.022 \\
\hline & & & $\beta_{2}$ & 0.01 & 0.01 & 0.038 \\
\hline \multirow{6}{*}{$\begin{array}{l}\text { Diplodus } \\
\text { annularis }\end{array}$} & \multirow{3}{*}{ Quadratic } & \multirow{3}{*}{ LP vs GTR } & $\beta_{0}$ & -27 & 5.62 & $<0.001$ \\
\hline & & & $\beta_{1}$ & 3.33 & 0.71 & $<0.001$ \\
\hline & & & $\beta_{2}$ & -0.98 & 0.02 & $<0.001$ \\
\hline & \multirow{3}{*}{ Quadratic } & \multirow{3}{*}{ SP vs GTR } & $\beta_{0}$ & -11.39 & 4.24 & 0.007 \\
\hline & & & $\beta_{1}$ & 1.35 & 0.56 & 0.017 \\
\hline & & & $\beta_{2}$ & -0.04 & 0.02 & 0.048 \\
\hline
\end{tabular}

3 
Figure 1

Map of the study area where the trials were performed in 2016 and 2017 (April-August).

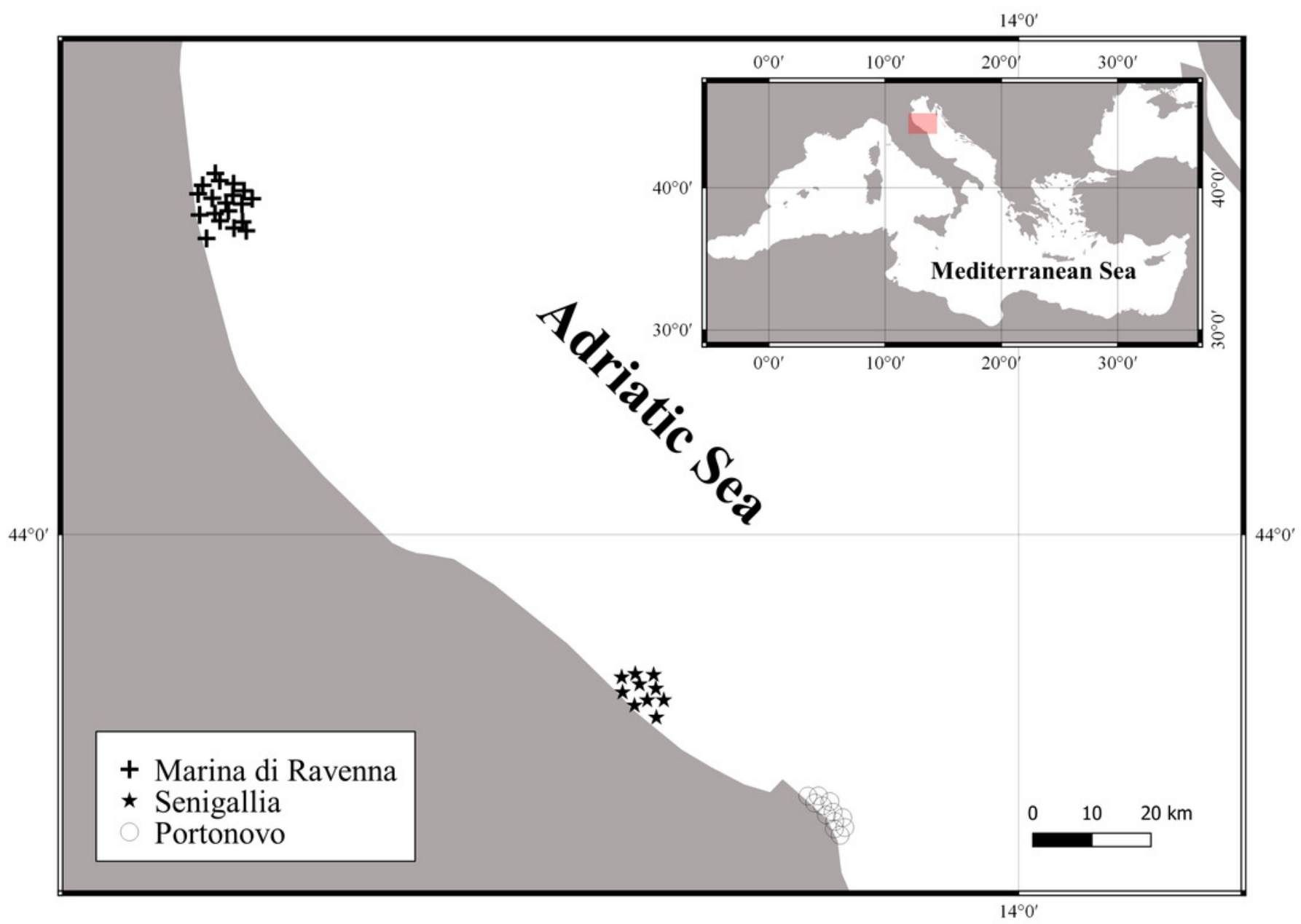


Figure 2

Scheme of the trammel net used in the study.

Inner panel: middle; outer panel: top and bottom. PA: polyamide; PP: propylene; ø: diameter;

E: hanging ratio.

$50 \mathrm{~m}$ PP $\varnothing 8$

263

$E=0.47$

PA Ø 210/3

$E=0.52$

$35 \quad \mathrm{PA} \varnothing 210 / 4$

1315

$72 \mathrm{~mm}$

$\mathrm{E}=0.54$

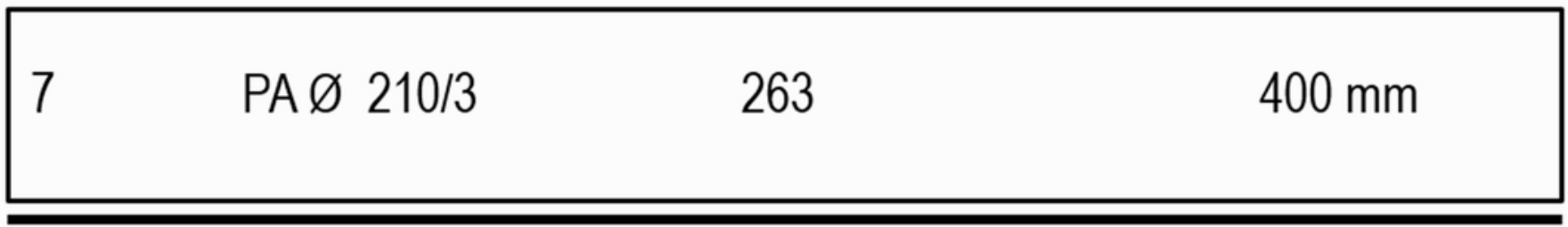

$50 \mathrm{~m}$ PP $\varnothing 10$

$120 \mathrm{~g} / \mathrm{m}$ 
Figure 3

Picture of the 'Trapula' pots tested in the study. See text for dimensions.

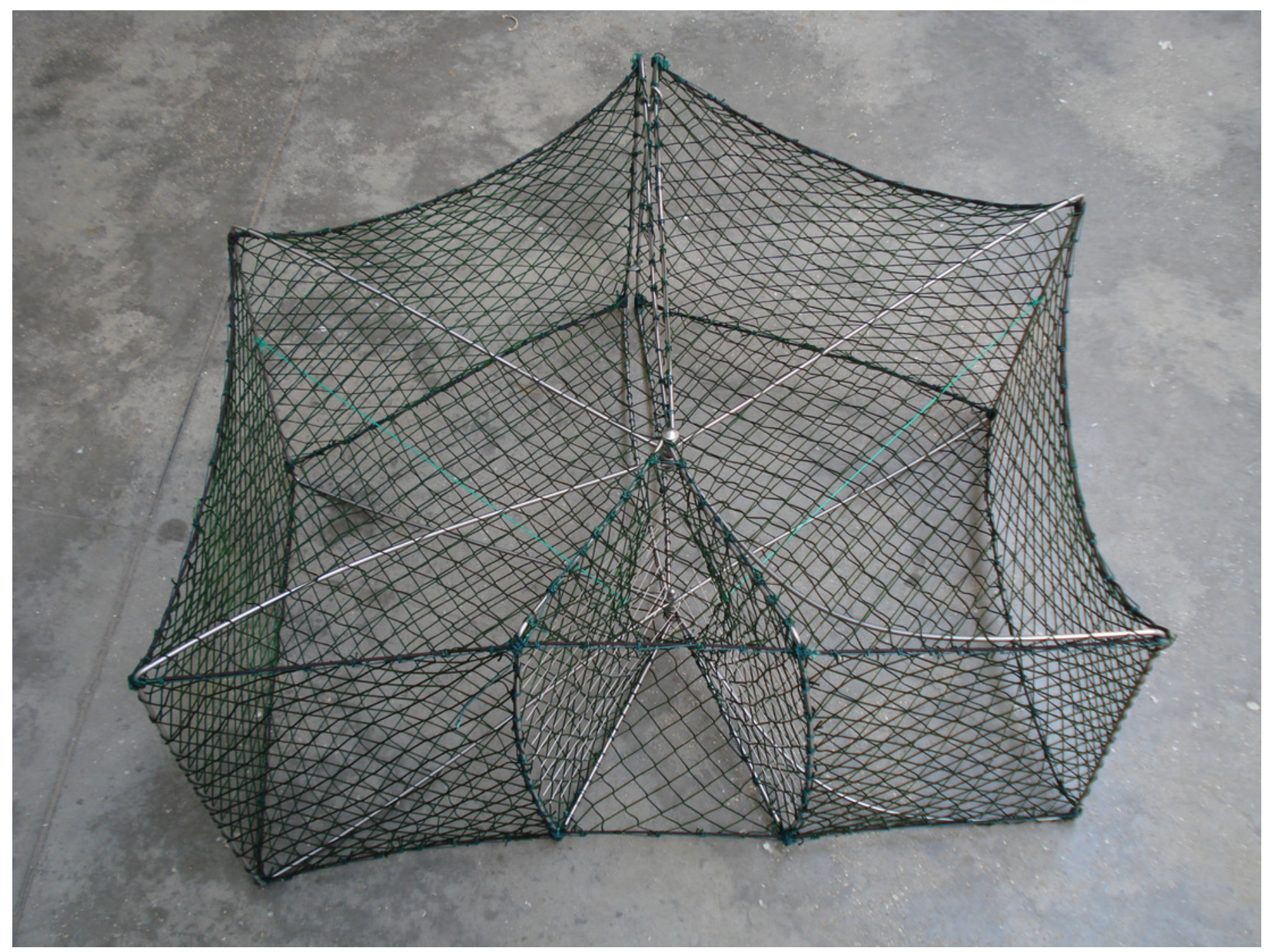


Figure 4

Overall CPUEw of landings and discards of the three gears tested in the study.

GTR: trammel nets; LP: large pots; SP: small pots. Red dots: mean $\mathrm{CPUE}_{\mathrm{w}}$; red bars:

confidence intervals (Cls). (A) Commercial; (B) Discard. 

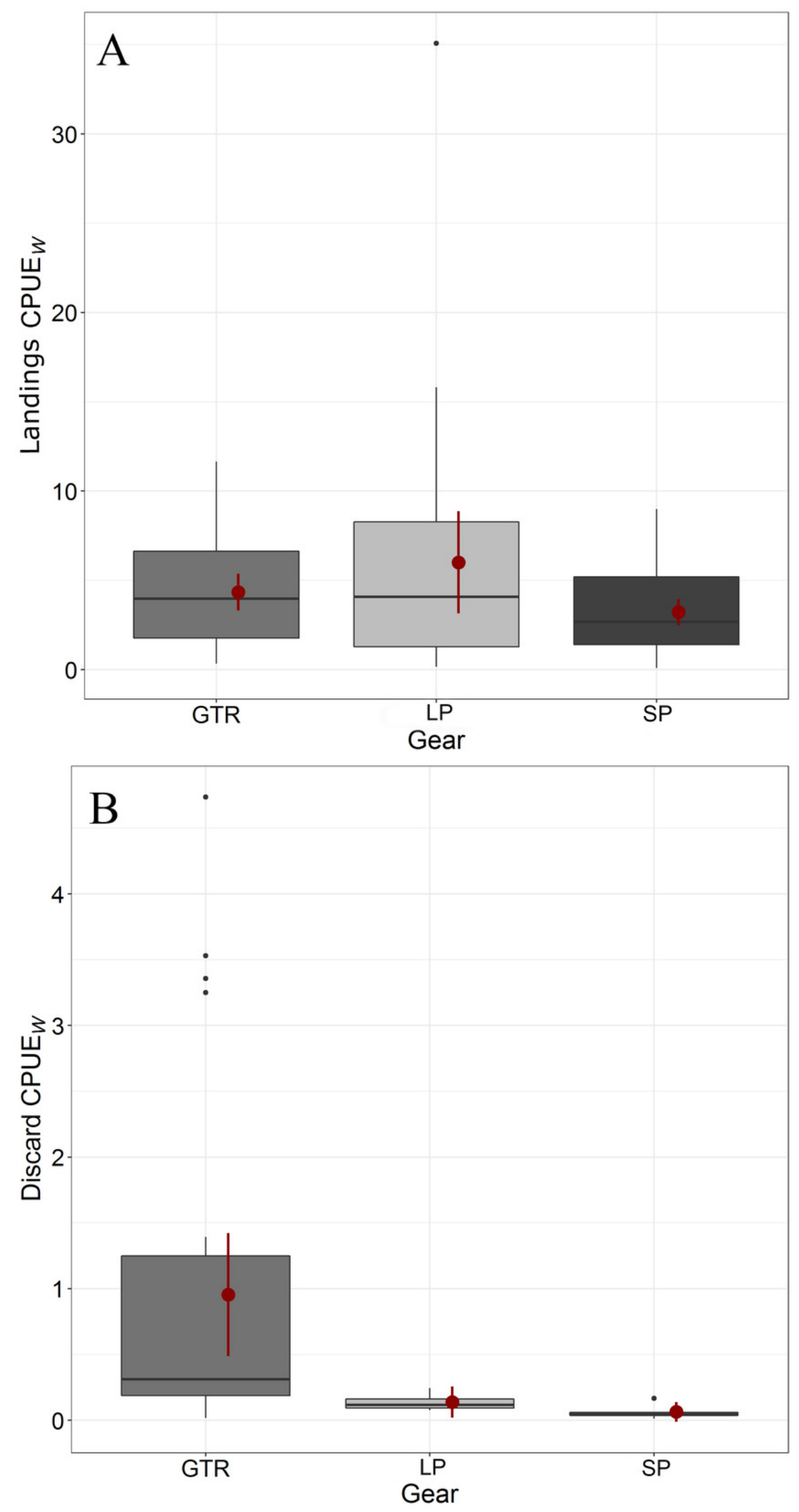

PeerJ reviewing PDF | (2019:12:43940:3:0:NEW 6 May 2020) 


\section{Figure 5}

Length frequency distributions (LFDs) of Sepia officinalis in each site $(A, B, C)$ and as a whole (D) and LFDs of Diplodus annularis in each site (E,F) and as a whole (G).

A,E: Marina di Ravenna, B: Portonovo, C,F: Senigallia. Dashed lines represent GTR (trammel nets); continuous lines represent SP (small pots); dotted lines represent LP (large pots); vertical dotted lines represent MCRS of $12 \mathrm{~cm}$ of $D$. annularis. 

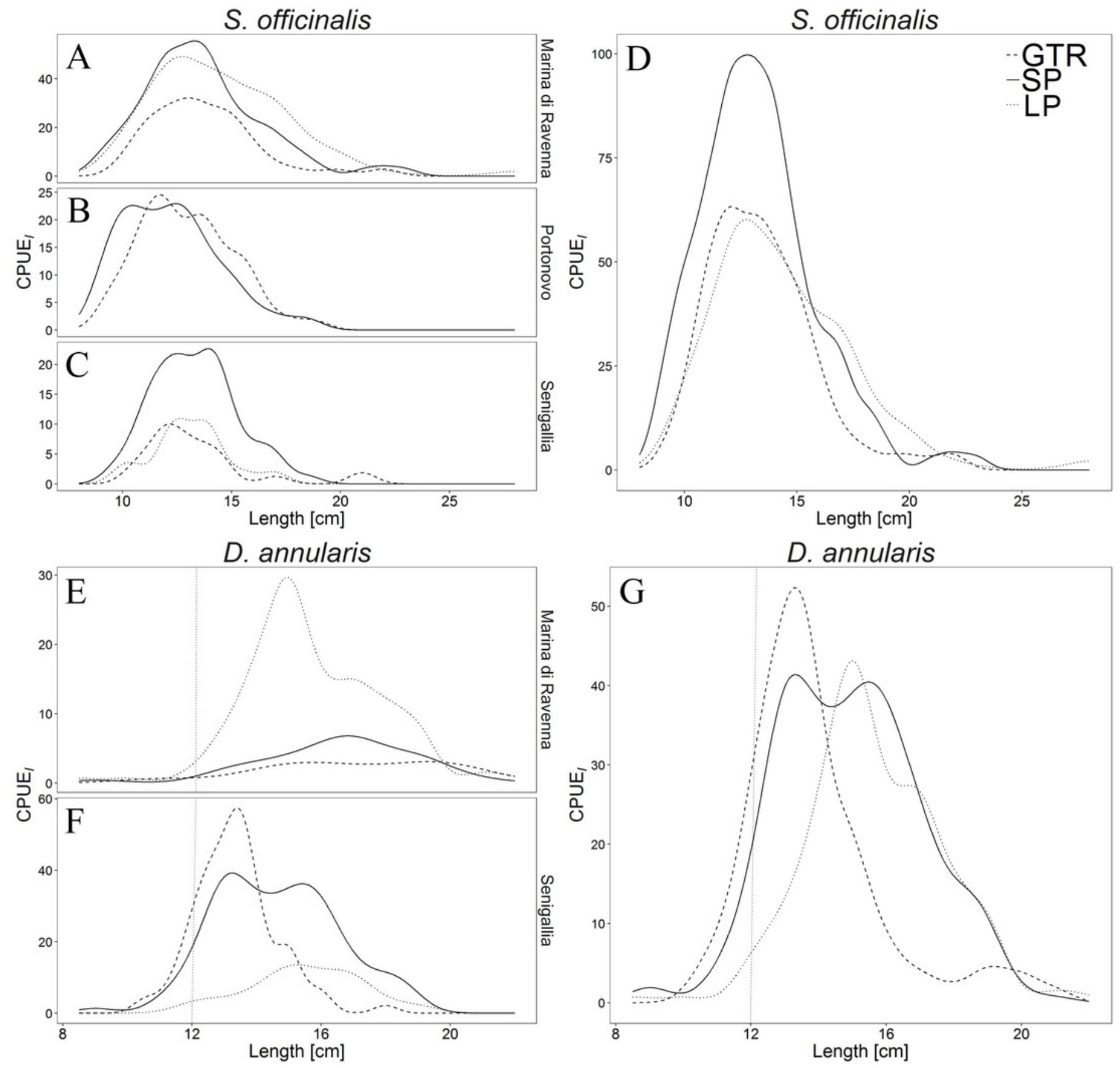


\section{Figure 6}

Catch comparison curves for Sepia officinalis (A) and Diplodus annularis (B), representing the GLMM proportions of the total catches of the three gears.

GTR: trammel nets; LP: large pots; SP: small pots. Dashed and dotted lines represent the mean proportions of LP and SP, respectively; the vertical dotted line represents MCRS of 12 $\mathrm{cm}$ of $D$. annularis. Interpretation: a value of 0.5 indicates an even split between GTRs and Pots, whereas a value of 0.25 indicates that the Pots caught $25 \%$ of all the fish of that length class whereas $75 \%$ were caught by the GTRs. Shaded areas: $95 \%$ confidence intervals. 

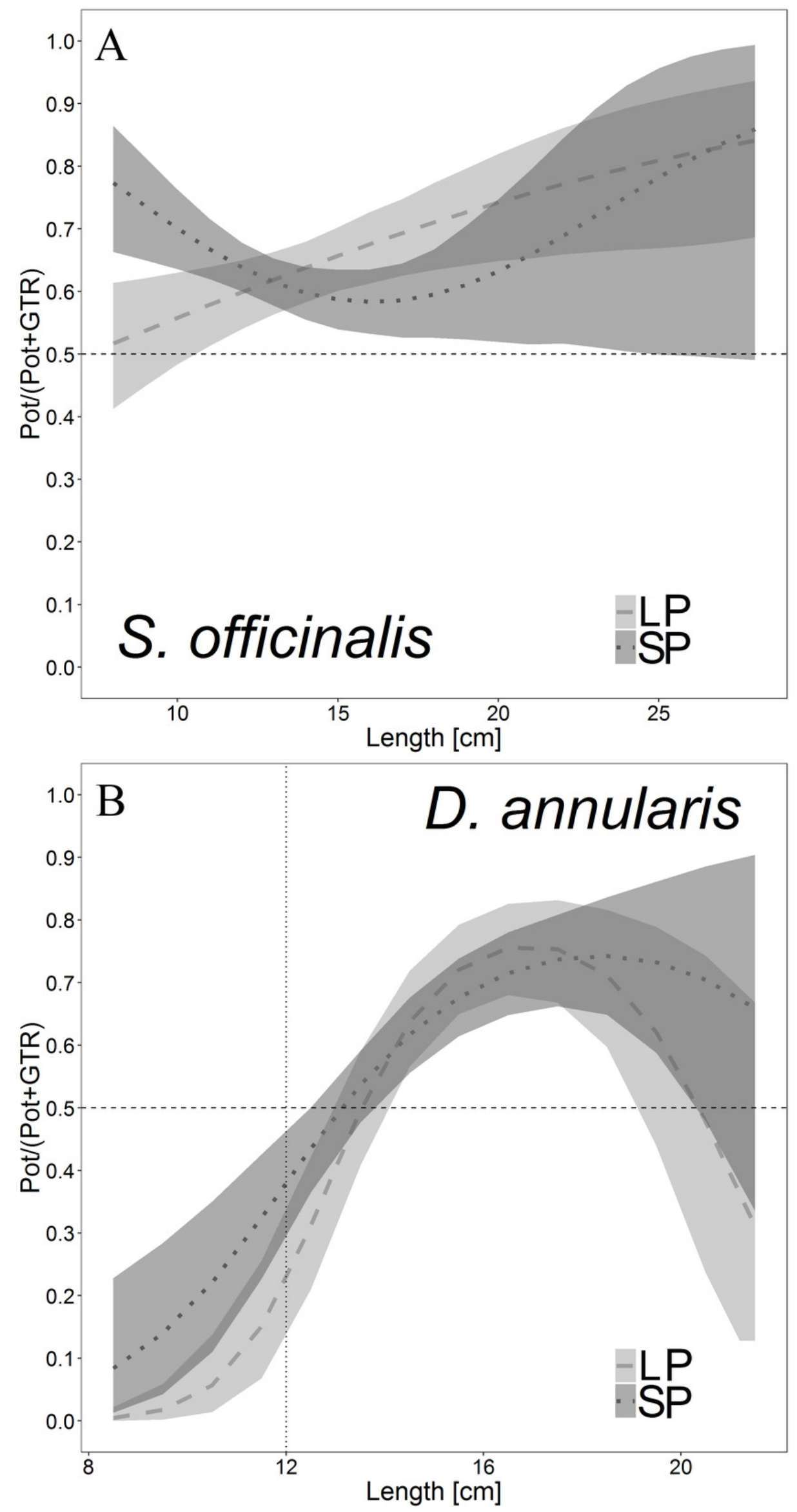

Peer) reviewing PDF | (2019:12:43940:3:0:NEW 6 May 2020) 